\title{
Pola Guru dalam Memotivasi Anak Studi terhadap Pola Guru di TK Islam dan TK Umum
}

\author{
Fidesrinur \\ Program Studi Pendidikan Anak Usia Dini, Fakultas Psikologi Pendidikan, \\ Universitas Al Azhar Indonesia, Jl. Sisingamangaraja, Jakarta 12110 \\ Penulis untuk Korespondensi/E-mail: fideza@uai.ac.id
}

\begin{abstract}
Abstrak - Tujuan utama pendidikan adalah mempersiapkan peserta didik untuk belajar mandiri. Pembentukan belajar mandiri memerlukan pembiasaan baik dari orang tua, pendidik ataupun guru. Pembiasan guru dalam pola memotivasi merupakan landasan untuk memperkenalkan cara belajar bagi anak. Pola motivasi guru yang terjadi dalam rutinitas kelas membentuk pola belajar anak. Pola guru lembaga PAUD Islam dan guru lembaga PAUD umum dalam memotivasi merupakan suatu fenomena yang menarik untuk dikaji guna memperoleh implikasinya terhadap pembelajaran PAUD. Hasil kajian menunjukkan bahwa: (1) pola motivasi guru lembaga PAUD Islam dan Umum sama-sama menekankan pola motivasi behavioristik, akan tetapi pola motivasi guru lembaga PAUD umum lebih bervariasi dalam menggunakan pola humanistik. Baik lembaga PAUD Islam dan lembaga PAUD Umum belum menerapkan kognitif sosial dan sosiolultural, (2) perbedaan pola motivasi guru PAUD umum dengan guru PAUD Islam dapat dibedakan didasari oleh pendekatan pembelajaran klasikal dan berbasis sentra. Kelas yang berbasis klasikal lebih berorientasi guru, sementara kelas yang berbasis sentra memberikan kesempatan yang lebih luas pada anak sehingga memugkinkan penggunaan pendekatan-pendekatan baru dalam memotivasi anak. (3) latar belakang perbedaan pola guru PAUD dalam memotivasi bersifat behavioristik karena penekanan pada membaca menulis dan berhitung yang lebih terukur dan dapat diamati. Disamping itu pendekatan pembelajaran berbasis klasikal atau berbasis sentra juga berimplikasi pada tingkat dominasi guru dalam proses pembelajaran.
\end{abstract}

Abstract - The objectives of any level of education is to make students to become independent learners. To become an independent learners children should be supported by parents, Early Childhood Education (ECE) teacher and community. At school, the ECE Teacher's Pattern on Motivation in daily classroom routines form students' habit formation. The differences of institution background between Islamic ECE teacher and Public ECE teacher become a phenomenon toward their own motivating perspectives which has its implication to children's way of learning. The research findings show that: (1) Both Islamic ECE teacher and the Public ECE teacher stress their teaching on behavioral motivation and none of them apply social cognitive nor socio cultural, though ECE public teacher more vary in applying humanistic motivation,(2) the differences of motivational pattern of the two are also characterized by whether its class is classical based or center based. The class with classical based is teacher oriented, where most of teaching is guided by teachers. On the other hand the center based class gives students more choices, so teacher may experience any approaches needed to match the students, and (3) the motivation based on behavioristic caused by teaching oriented on reading, writing and counting where its fit to measure and observe learning outcomes. Besides, the pattern of motivation also influenced by whether the class classical-based or centerbased where each of them vary in whether stressing on teacher or on students.

Keywords - Teacher's Pattern on Motivation, Behavioral Approach, Humanistic Approach, cognitive and Social Approach, Social Cultural Conception Approach. 


\section{PENDAHULUAN}

$\mathrm{T}$ ujuan utama pendidikan atau pembelajaran adalah untuk mempersiapkan peserta didik untuk belajar mandiri. Belajar mandiri tidak begitu saja dapat dimiliki oleh peserta didik tanpa melalui bantuan orang tua, pendidik ataupun guru. Untuk belajar mandiri perlu dikembangkan motivasi belajar anak sedini mungkin. Untuk itu masa kanak-kanak adalah masa yang sangat strategis untuk mengembangkan pembelajaran yang mandiri sehingga berguna membelajarkan saat masih anak-anak dan masa dewasa nantinya.

Pembelajaran anak yang berakar dari pembelajaran yang dilakukan guru merupakan dasar untuk mengembangkan lingkungan yang nyaman dalam membelajarkan anak. Dari pengalaman sehari-hari kita dapat melihat adanya perbedaan cara anak dalam belajar yang merupakan implikasi dari rasa nyaman anak dalam belajar. Rasa nyaman terhadap lingkungan tertentu dalam pembelajaran merupakan sesuatu yang perlu ditumbuhkan sedini mungkin sehingga daya juang anak juga kan ditentukan oleh lingkungan yang dibiasakan dalam membentuk cara belajar anak. Rasa nyaman ini terkait dengan lingkungan yang mendorong anak untuk termotivasi dalam belajar.

Motivasi merupakan faktor penting dalam proses pendidikan dan pembelajaran. Motivasi merupakan sesuatu yang unik dalam diri manusia. Keunikan manusia tersebut dapat dilihat dari masing-masing manusia mempunyai kekhasan sendiri atas hal yang dapat memotivasinya. Demikian juga faktor-faktor yang dapat memotivasi anak dalam belajar. Walaupun dari berbagai teori diketahui bahwa ada motivasi yang berasal dari dalam individu dan ada pula motivasi yang berasal dari luar diri individu itu sendiri. Namun dalam kenyataannya kedua motivasi internal dan motivasi ekternal tersebut merupakan satu kesatuan yang utuh dan tidak terpisahkan dalam pelaksanaanya.

Pengalaman menunjukkan bahwa waktu yang cukup lama belum menjamin bahwa sesorang dapat memotivasi orang lain, termasuk dalam memotivasi anak sendiri. Orang tua yang paling dekat dengan anak misalnya tidak selalu dapat memotivasi anaknya walaupun ia yang melahirkan dan membesarkan, serta merawatnya dari waktu ke waktu. Kenyataan ini menunjukkan bahwa kedekatan anak secara fisik belum sepenuhnya menjamin efektivitas orang tua dalam memotivasi anak.

Kenyataan lain menunjukan bahwa anak seringkali merujuk apa yang dikatakan gurunya untuk pembenaran dalam melakukan sesuatu dalam kegiatan sehari-hari. Seringkali kita mendengar anak-anak di rumah bicara dengan ibu atau bapaknya yang mengatakan,"kata ibu guru tidak begitu, kata ibu guru begini". Ini menunjukkan bahwa guru merupakan referensi bagi anak dalam bersikap dan berperilaku. Acuan berbuat dan berperilaku ini tentu tidak hanya terbatas pada sesuatu yang dianggap benar atau salah atau yang dianggap betul atu salah. Lebih dari itu dalam jangka waktu panjang guru juga akan mempengaruhi cara belajar anak. Para ahli mengemukan bahwa ada kecenderungan seseorang itu belajar sebagaimana ia diajar oleh oleh gurunya. Hal yang sama juga sering disamakan antara cara mengajardan cara belajar guru diidentikkan dengan anak didiknya.

Kenyataan kesulitan mengahadapi anak oleh orang tua sendiri disatu sisi dan panutan murid terhadap guru menyiratkan beratnya tugas guru dalam menumbuhkan cara belajar anak. Disamping itu guru juga dilihat anak sebagai sosok berarti bagi anak dalam mendorong mereka untuk belajar sesuai dengan arahan gurunya. Ini berarti guru berfungsi sebagai motivator bagi anak dalam belajar dan sekaligus dalam menumbuhkan minat belajar pada anak. Dengan posisi strategis yang dimiliki guru dalam memotivasi anak ini akan memberikan pola belajar pada anak.

Guru dalam memperoleh pengalaman memotivasi tentu juga memerlukan waktu yang lama dan melalui proses pembelajaran baik melalui gurunya maupun melalui informasi-informasi pengetahuan baru tentang motivasi. Dengan berjalannya waktu tentu pengalaman tanpa pengetahuan yang memadai tentang cara memotivasi anak dapat merugikan perkembangan anak. Padahal usia dini diyakini sebagai masa emas yang tidak akan terulang kembali dan berdampak pada cara belajar anak sepanjang hayat.

Untuk itu pengetahuan tentang motivasi merupakan ilmu yang sangat penting bagi guru. Pengetahuan tentang motivasi merupakan langkah yang tepat untuk meningkatkan kemampuan guru dalam berinteraksi dengan anak. Apalagi pengetahuan tentang motivasi merupakan hasil penelitian yang telah dilaksanakan secara 
berulang-ulang baik dengan menggunakan hewan, manusia maupun hasil karya psikologi klinis dan industri yang dilaksanakan dengan berbagai konteks situasi yang melatar belakanginya. Keterujian teori-teori motivasi yang dikembangkan oleh para ahli merupakan langkah pintas yang dapat dilakukan guru untuk memahami kompleksitas kehidupan anak, terutama dalam kiat-kiat memotivasi anak dalam belajar.

Pola motivasi yang dilakukan secara berulangulang oleh guru akan menjadi pola pembiasan belajar bagi anak. Pola pembiasaan yang dilakukan guru ini selanjutnya akan berdampak pada pola belajar murid. Pola belajar murid ini dapat membentuk pola pemrosesan informasi dalam pembelajaran anak dalam jangka panjang. Dengan kata lain pola motivasi pembelajaran yang dikembangkan oleh guru tidak hanya akan mejadi alat untuk pembelajaran saat itu tetapi berpengaruh pada strategi anak sepanjang hayatnya.

Sehubungan dengan begitu besarnya pengaruh motivasi guru pada strategi belajar anak dalam jangka panjang maka penelitian yang berjudul "POLA GURU PAUD DALAM MEMOTIVASI ANAK: Studi terhadap Pola Guru di TK Islam dan TK Umum".

\section{Masalah Penelitian}

Berdasarkan pemahaman tentang kecerdasan ganda atau multiple intelegence diketahui bahwa masing-masing-masing anak mempunyai kekuatan dan kelemahannya masing-masing sesuai dengan kecerdasan yang dimilikinya. Implikasi dari kecerdasan ini juga memberikan pemahaman bahwa masing-masing anak berbeda-beda pula dalam cara memperoleh informasi, gaya belajar sesuai dengan potensi yang dimilikinya masingmasing. Semua ini menunjukkan bahwa cara-cara yang dapat memotivasi anak tentu juga berlainan antara satu anak dengan anak yang lainnya. Disisi lain guru mempunyai pola dan cara tersendiri pula dalam memotivasi anak dalam belajar.

Keseusaian pola motivasi yang diberikan dengan kecenderungan anak dalam belajar merupakan faktor penting dalam mendorong anak dalam motivasi belajar. Ketepatan dalam pemilihan faktor-faktor yang memotivasi anak merupakan upaya yang membuat anak merasa nyaman dalam belajar. Rasa nyaman dan suasana menyenangkan merupakan salah satu syarat dalam pembelajaran anak yang dapat mendorong anak giat dalam belajar. Belajar dengan giat pada usia dini perlu dibiasakan agar perilaku belajar mereka terbentuk sedmikian rupa sehingga kebiasaan dalam belajar dapat tumbuh yang akan berpengaruh pada pembelajaran pada pendidikan lebih lanjut. Pengalaman menunjukkan bahwa permasalahan utama dalam belajar dewasa ini adalah rendahnya motivasi siswa dalam belajar sebagai akibat pola motivasi yang terbentuk dari kecil sulit berubah.

\section{Pembatasan masalah}

Masalah penelitian ini dibatasi pada gambaran tentang pola motivasi yang digunakan oleh guru PAUD dalam memotivasi anak dalam belajar. Pola motivasi guru merupakan representasi pemahaman guru dalam memahami faktor-faktor yang memotivasi anak. Sebagaimana yang dikemukakan dalam permasalahan penelitian ini bahwa masing-masing anak mempunyai pola yang dapat memotivasi mereka dalam belajar. Kenyataan ini berartipula bahwa masing-masing guru harus dapat menyesuaikan pola motivasi yang tepat sesuai dengan kebutuhan anak. Pengalaman dan pemahaman guru yang beragam dalam memotivasi anak berimplikasi pada kebiasaan guru dalam memotivasi serta terus berupaya untuk menyesuaikan bentuk-bentuk motivasi yang dikembangkan guru sesuai dengan kebutuhan anak.

\section{Perumusan masalah}

Sehubungan dengan pembatasan masalah penelitian, maka perumusan masalah dapat dikemukakan sebagai berikut:

1. Bagaimana gambaran pola motivasi guru PAUD dalam pembelajaran?

2. Apakah terdapat perbedaan pola motivasi guru PAUD umum dengan guru PAUD Islam?

3. Apakah yang melatar belakangi perbedaan pola guru PAUD dalam memotivasi murid dalam di PAUD?

\section{Signifikansi Masalah}

Pembelajaran anak usia dini dalam suasana bermain dan menyenangkan merupakan prasyarat dalam pembelajaran bagi anak. Untuk itu pembelajaran sesuai kebutuhan anak baik sesuai perkembangan, sesuai individual, dan sesuai sosial budaya. Dalam mempertimbangkan ketiga kesesuain perkembangan, individual dan sosial budaya anak. Semua itu menunjukkan bahwa masing-masing anak mempunyai cara-cara tertentu dalam memotivasi anak dan faktor-faktor yang dapat memotivasinya. Perbedaan masing-masing faktor yang dapat memotivasi anak ini akan 
berdampak luas dan berkelanjutan pada pembelajaran anak sepanjang hayat. Untuk itu kajian tentang pola motivasi guru PAUD penting untuk dikaji karena terkait dengan pendidikan anak selanjutnya.

\section{KAJIAN TEORETIS}

\section{Motivasi dalam Pendidikan Anak Usia Dini}

Kemampuan guru dalam memotivasi anak pada dasarnya tidak jauh berbeda dengan kemampuan yang harus dimiliki oleh seorang dokter dalam mengobati pasiennya. Dokter dalam pelaksanaan tugas misalnya, membuat perkiraan dosis obat berdasaran kemampuan dokter mendiagnosa atas indikasi yang tampak. Obat akan efektif apabila diagnosa yang dibuat tepat atau sesuai dengan kebutuhan pasien. Sementara itu motivasi yang diberikan oleh guru juga harus sesuai dengan dosis yang diperlukan oleh masing-masing anak. Dosis motivasi dapat berupa cara memotivasi dan waktu yang tepat untuk memotivasi anak. Perbedaan dokter dengan guru hanya terletak pada hasil pekerjaanya yang segera dapat terlihat, sementara hasil pendidikan terkadang membutuhkan waktu yang lama sehingga efek kesalahan diagnosa belajar merupakan akumulasi dari kesalahan-kesalahan sebelumnya sehingga sulit dan bahkan tidak dapat diatasi karena tidak ada waktu lagi untuk memperbaikinya.

Keterlambatan waktu dalam memotivasi ini makin terasa apabila bekerja sebagai pendidik PAUD. Guru diharapkan dapat mengoptimalkan masa emas "golden age" dimana perkembangan kognitif, bahasa dan sosial emosional mengalami titik puncaknya. Hasil penelitian membuktikan bahwa pendidikan anak usia dini yang baik mempengaruhi perkembangan otak anak, kesehatan anak, kesiapan anak bersekolah, kehidupan sosial dan ekonomi yang lebih baik jika kelak telah dewasa dibandingkan dengan anakanak yang kurang terdidik pada usia dini.

Dalam kaitan ini guru perlu mengetahui keunikan dan kekompleksan masing-masing perkembangan anak, karena walaupun secara umum urutan pentahapan dan milestone dapat diprediksi, namun prosedur perkembangan dalam tahapan perkembangan ini memiliki cara dan waktu berbeda-beda. Disamping itu perkembangan anak juga sangat dipengaruhi oleh faktor-faktor lingkungan dan pengalaman yang dimiliki anak.

Untuk itu pendidik PAUD dituntut serba bisa dan menguasai beberapa cabang ilmu untuk mengakomodasi kepentingan anak seperti kesehatan, Matematika, Psikologi, Sosial, Pendidikan, Kesadaran Lingkungan, Moral dan lain sebagainya. Namun yang tidak kalah pentingnya dari semua itu adalah bagaimana motivasi yang diberikan guru dapat membelajarkan anak ke arah kemandirian belajar yang diinginkan oleh anak sesuai dengan gaya belajarnya sendiri.

Kegagalan pendidikan sudah merupakan keluhan yang umum didengar di masyarakat, baik keluhan dari orang tua, masyarakat maupun keluhan dari pendidik, terutama perilaku anak yang tidak sesuai dengan harapan dan tujuan pendidikan. Kegagalan demi kegagalan ini menyadarkan pendidik bahwa ada suatu kejadian yang secara tidak sadar telah membentuk karakter anak sehingga sulit untuk diubah. Menurut Anderson kejadian ini sangat ironis karena tujuan sangat penting bersifat intensional dan beralasan [1]. Pengajaran bersifat intensional karena kita mengajar untuk tujuan tertentu, utamanya untuk memfasilitasi pembelajaran anak. Pengajaran beralasan karena apa yang diajar guru pada anak adalah sesuatu yang bermanfaat bagi anak.

Seandainya guru telah berupaya merencanakan pembelajaran sedemikian rupa, tetapi kenyataan menunjukan hasil pendidikan tidak bermanfaat maka ada sesuatu yang salah dalam proses pendidikan yang dilakukan. Zais menyebut gejala ini sebagai kurikulum tersembuyi "hidden curriculum" yaitu kurikulum yang tidak direncanakan atau yang tidak diharapkan [2].

Berbabagai upaya telah dilakukan agar hasil pendidikan anak usia dini berkembang lebih baik, diantara sangat dikenal dan ditiru di seluruh dunia misalnya Pendekatan Montessory, Bank Street, Reggio Emilia, High/Scope, Creative Curriculum dan lain sebagainya. Dalam kaitan itu pula, pada tahun 1978 pertama kali panduan Developmentally Appropriate Practices (DAP) untuk usia lahir sampai 8 tahun diperkenalkan oleh the National Association for the Education of Young Children (NAEYC) di Amerika Serikat [3]. Panduan ini dimaksudkan untuk (1) meningkatkan kualitas pendidikan anak usia dini atas dasar pengetahuan tentang praktek sesuai perkembangan anak; dan (2) agar pendidikan anak usia dini mendapatkan pengakuan politik sebagai sebuah pekerjaan profesional dari pemerintah maupun masyarakat secara luas. Dalam perjalananya, panduan DAP ini mengalami 
berbagai macam kritikan, ketidakpastian dan mitos dari profesional pendidikan lainnya. Akhirnya DAP menjadi kertas kerja hipotesis yang selalu mengalami perubahan dan berproses secara dinamis bersamaan dengan kritik dan refleksi terhadap praktek PAUD.

Selanjutnya Gestwicki dalam perkembangannya DAP diterjemahkan dari berbagai macam sudut pandang baik teori maupun praktek sebagai berikut: (1) kerangka, suatu filosofi atau suatu pendekatan untuk bekerja dengan anak usia dini; (2) menterjemahkan pengetahuan tentang perkembangan anak serta implikasinya terhadap pelaksanaan pengasuhan dan pendidikan anak usia dini; (3) aplikasi pengetahuan tentang perkembangan anak agar pengambilan keputusan untuk program kegiatan anak usia dini secara seksama mempertimbangkan kesesuaian usia, tahapan perkembangan, konteks lingkungan, kemampuan anak; (4) tidak merupakan sebuah kurikulum.

Implikasi dari uraian di atas adalah bahwa DAP dapat memberikan inspirasi pemilihan pendekatan pembelajaran yang relevan sesuai perkembangan anak atas dasar teoretis dan logika empiris guna meminimalkan intuisi atau pembelajaran yang didasari oleh kata hati semata. Satu hal penting dari DAP adalah bagaimana pendidik PAUD bereksperimen berdasarkan dari fakta dan data observasi langsung dalam kegiatan anak sehingga memberikan inspirasi bagi pendidikan yang relevan dengan perkembangan anak.

\section{Pengertian Motivasi dalam Pembelajaran bagi PAUD}

Motivasi seringkali dijadikan momok untuk anak yang tidak mau belajar. Anak-anak yang sulit diajak untuk berlama-lama dalam belajar merupakan permasalahan umum dalam pembelajaran bagi anak usia dini. Untuk itu perlu diketahui apa yang dapat menggerakkan ank untuk belajar dengan baik. Setiap orang termasuk anak dalam melakukan suatu kegiatan digerakkan oleh suatu dorongan untuk melakukan sesuatu yang dikenal dengan motivasi. Menurut Schunk, kata motivasi berasal dari kata kerja bahasa Latin movere (bergerak) atau sesuatu yang membuat kita bergerak, membuat kita terus bekerja dan membantu kita untuk menyelesaikan tugas-tugas [4]. Ada beberapa pendapat yang berbeda dalam mendefinisikan motivasi. Dalam teori behaviorisme (conditioning), motivasi adalah suatu peningkatan respon atau respon yang berkelanjutan terhadap stimulus yang disebabkan oleh penguatan (reward). Sedangkan menurut teori koginitif motivasi adalah pemikiran individu, keyakinan dan emosi yang mempengaruhi motivasi.

Senada dengan pemikiran berdasarkan asal usul kata motivasi tersebut Yudhawati mengemukakan bahwa motivasi adalah kekuatan (energi) seseorang yang dapat menimbulkan tingkat persistensi dan antusiasmenya dalam melaksanakan suatu kegiatan, baik yang bersumber dari dalam diri individu sendiri (motivasi intrinsik) maupun dari luar individu (motivasi ekstrinsik). Artinya seseorang anak yang termotivasi dapat dilihat dari lamanya anak serta semangatnya terlibat dalam suatu kegiatan baik yang didorong dari dalam diri maupun dari luar diri anak yang bersangkutan. Dalam kaitan itu pula pakar teori motivasi diantara Graham \& Weiner dkkk dalam Woolfolk mengemukakan bahwa motivasi adalah keadaan internal yang membangkitkan, mengarahkan dan mempertahankan perilaku [5].

Sebelum mengkaji motivasi instrinsik dan ekstrinsik menurut Schunk perlu dibedakan antara minat dengan motivasi [4]. Minat adalah kesukaan dan kemauan terlibat dalam suatu aktivitas. Minat seseorang relatif bersifat menetap terhadap suatu topik tertentu atau domain, dan situasi yang diminati yang bersifat temporer dan situasional dalam memperhatikan suatu topik. Minat bukanlah motivasi tetapi berpengaruh terhadap motivasi. Siswa yang tertarik dalam mempelajari suatu topik tertentu akan menunjukkan perilaku termotivasi seperti pemilihan aktivitas, upaya yang dilakukan, keseriusan perhatian dan prestasi.

Mengacu kepada pandangan motivasi yang dikemukakan oleh berbagai pakar dimana sebagian besar ahli memandang motivasi intrinsik dan motivasi instrisik sebagai pandangan klasik yang menjadi sumber inpirasi motivasi berbagai macam teori. Menurut Graham \& Weiner dkkk dalam Woolfolk, pengerian motivasi intrinsik, adalah kecenderungan alamiah untuk mencari dan menaklukkan tantangan ketika individu tersebut mengejar kepentingan pribadi dan menerapkan segala kemampuan yang dimilikinya [5]. Sementara itu bila individu termotivasi secara instrinsik, individu tersebut tidak membutuhkan insentif atau hukuman karena kegiatan itu sendiri memberikan penguatan; sebaliknya pengertian motivasi ekstrinsik, adalah melakukan sesuatu 
untuk mendapatkan nilai, menghindari hukuman, membuat guru senang atau alasan lainnya yang sedikit sekali kaitannya dengan dengan tugas tersebut. Sementara itu secara sederhana Santrock mengemukakan bahwa motivasi intrinsik adalah motivasi internal untuk melakukan sesuatu demi sesuatu itu sendiri (tujuan itu sendiri); sedangkan motivasi instrinsik adalah melakukan sesuatu untuk mendapatkan sesuatu yang lain (cara untuk mencapai tujuan) [6].

Disisi lain para psikolog ada yang berpendapat bahwa mustahil motivasi dapat diketahui hanya melalui konsep motivasi internal dan eksternal. Perbedaan penting dari kedua konsep itu adalah apakah letak penyebab (locus of causality) tindakan internal dan eskternal individu tersebut. Salah satu penjelasannya adalah kegiatan individu terletak disepanjang kontinum mulai dari seenuhnya self-determined (atas dasar tekad sendiri/motivasi intrinsik) sampai determined by others (sepenuhnya ditentukan oleh orang lain/motivasi eksrinsik). Bahkan baru-baru ini gagasan tentang motivasi intrinsik dan ekstrinsik sebagai dua ujung kontinum telah ditantang. Salah satu penjelasan alternatifnya adalah karena motivasi dapat memasukkan faktor-faktor trait (sifat), maupun state (keadaan), maka ia juga dapat memasukkan faktor-faktor instrinsik dan ekstrinsik. Kecenderunagn intrinsik dan ekstrinsik adalah dua kemungkinan yang independen dan pada waktu tertentu setiap individu dapat dimotivasi oleh sebagian dan masing-masing kecenderungan itu.

Dari uraian di atas dapat dikatakan bahwa motivasi adalah proses dorongan atau kekuatan individu untuk aktivitas yang terarah pada tujuan diperkuat dan dipertahankan baik yang bersumber dari dalam diri individu maupun yang bersumber dari luar diri individu tersebut.

\section{Kajian Teori Pola Motivasi dari Berbagai Pendekatannya}

Motivasi adalah subjek yang sangat luas dan kompleks mencakup banyak teori. Sebagian teori dikembangkan melalui penelitian dengan binatang di laboratorium, yang lainnya didasarkan pada penelitian pada manusia dalam situasi-situasi yang menggunakan permaianan dan teka-teki. Sebagian teori muncul dari hasil karya yang dilakukan dalam bidang psikologi klinis dan industri. Untuk mempermudah kajian tentang motivasi dalam pembelajaran dan pengajaran maka dalam pembahasan ini akan mengikuti empat pendekatan umum motivasi yang dikemukan Woofol yaitu: (1) pendekatan berhavioral, (2) pendekatan humanistik, (3) pendekatan kognitif dan kognitif sosial, dan (4) konsepsi sosiokultural [5].

\section{Pendekatan Behavioral}

Pemahaman tentang motivasi siswa dimulai dengan analisis secara seksama atas insentif dan reward. Reward adalah objek atau kejadian yang menarik yang diberikan sebagai konsekuensi perilaku tertentu. Insentif adalah objek atau kejadian yang mendorong atau menekan perilaku. Janji untuk mendapatkan nilai $A$ adalah insentif bagi siswa. Benar-benar menerima nilai A adalah reward. Bila secara konsisten memperkuat perilaku tertentu, kita dapat mengembangkan kebiasaan atau kecenderungan untuk bertindak dengan cara tertentu.

Pendekatan behavioral juga dikemukakan oleh Emmer dalam Santrock memandang bahwa imbalan dan hukuman merupakan kunci dalam menentukan motivasi murid [6]. Insentif adalah peristiwa atau stimuli positif atau negatif yang dapat memotivasi perilaku murid. Pendukung penggunaan insentif menekankan bahwa insentif dapat menambah minat atau kesenangan pada pelajaran, dan mengarahkan perhatian pada perilaku yang tepat dan menjauhkan mereka dari perilaku yang tidak tepat.

Untuk mengaplikasikan prinsip-prinsip behaviorisme di kelas menurut Schunk aplikasi teori behavioral di kelas: (1) pastikan siswa siap untuk belajar, (2) bantu anak membentuk asosisasi antara stimulus dan respon, (3) memberikan gambaran tentang belajar dan aktivitas kelas dengan hasil yang menyenangkan, (4) memberi penguatan pada perilaku yang diharapkan dan memperlemah perilaku yang tidak diharapkan, (5) memberi penguatan kemajuan dalam pembelajaran dan perilaku, (6) memberikan kesempatan berpartisipasi pada aktivitas yang bernilai dan mengurangi kegiatan-kegiatan yang kurang bermanfaat [4].

\section{Pendekatan Humanistik}

Pada tahun 1940-an , para pendukung psikologi humanistik seperti Carl Rogers mengatakan bahwa tidak ada aliran psikologi yang dominan, behavioral atau Freudian yang dapat menjelaskan secara tepat mengapa orang bertindak dengan cara tertentu. Interpretasi humanistik tentang motivasi menekankan sumber-sumber instrinsik motivasi 
seperti kebutuhan orang akan aktualisasi diri, kecenderungan untuk mengaktualisasikan mulai sejak lahir, atau kebutuhan akan determinasi diri. Jadi menurut pandangan humanistik, memotivasi berarti mendorong sumber daya dari dalam diri orang, rasa kompetensi, self-esteem, otonomi dan aktualisasi diri mereka. Teori Maslow adalah salah satu penjelasan humanistik yang sangat berpengaruh tentang motivasi.

Menurut Santrock perspektif humanistis menekankan pada kapasistas murid untuk mengembangkan kepribadian, kebebasan untuk memilih nasib merek [6]. Kualitas positif (seperti peka terhadap orang lain). Perspektif ini berkaitan dengan pandangan Maslow bahwa kebutuhan dasar tertentu harus dipuaskan terlebih dahulu sebelum memuaskan kebutuhan yang lebih tinggi.

Menurut Maslow manusia memiliki hirarki kebutuhan yang berkisar mulai kebutuhan kebutuhan yang lebih rendah seperti bertahan hidup dan keamanan sampai kebutuhankebutuhan yang lebih tinggi yaitu Self esteem atau kebutuhan -kebutuhan defisiensi untuk mencapaian prestasi intelektual dan akhirnya aktualisasi diri (being needs/kebutuhan menjadi). Bila kebutuhan-kebutuhan ini terpenuhi, motivasi seseorang tidak akan menghilang, ia meningkat untuk mencari pemenuhan lebih lanjut. Berbeda dengan kebutuhan defisiensi, being needs tidak pernah sepenuhnya terpenuhi.

Teori Maslow dikritik bahwa orang tidak selalu tampak berperilaku sebagaimana diprediksi oleh teori itu. Kebanyakan orang bergerak maju mundur di antara berbagai macam kebutuhan dan bahkan dimotivasi oleh banyak kebutuhan yang berbeda sekaligus. Sebagian orang mengabaikan keamanan dan pertemanan untk mencapai pengetahuan, pemahaman, atau self-esteem yang lebih besar.

Untuk mengaplikasikan prinsi-prinsip humanistik di kelas Menurut Schunk, aplikasi teori humanistik di kelas: (1) menunjukkan harapan yang positif pada siswa, (2) pisahkan siswa dari tindakan mereka; menerima mereka apa adanya daripada bagaimana mereka bertindak, (3) mendorong pertumbuhan personal dengan memberikan kesempatan pada siswa untuk memilih dan kesempatan untuk memulai aktivitas pembelajaran dan pencapaian tujuan, (4) membuat kontrak dan memberi kesempatan kepada siswa untuk mengevaluasi pembelajaran mereka, (5) memfasilitasi pembelajaran dengan menyediakan sumber-sumber belajar dan penguatan bagi siswa [4].

\section{Pendekatan Kognitif dan Kognitif Sosial}

Dalam teori-teori kognitif, orang dianggap aktif dan ingin tahu mencari informasi untuk mengatasi masalah-masalah yang dihadapinya secara pribadi. Para pakar koginitif menekankan pada motivasi intrinsik. Dalam banyak hal, teori kognitif tentang motivasi juga berkembang karena reaksi atas padangan-pandangan behavioral. Para pakar teori kognitif percaya bahwa perilaku ditentukan oleh pikiran kita, bukan semata-mata oleh apakah kita diberi reward atau hukuman untuk perilaku itu di masa lalu; perilaku diprakarsasi dan diregulasi oleh rencana; tujuan, skema, ekspektasi dan atribusi.

Menurut Schunk, menunjukkan pentingnya pengaruh koginitif sosial dalam mempengaruhi perilaku: manusia memperoleh pengetahuan, aturan-aturan, keterampilan, strategi, keyakinan dan emosi dengan mengamati orang lain [4]. Manusia juga mempelajari model tindakan yang cocok dengan cara mengamati konsekuensi tindakan tersebut. Pendekatan kognitif sosial bahwa tindakan individu didasari oleh pemikiran, tujuan, keyakinan dan nilai-nilai.

Untuk mengaplikasikan prinsi-prinsip kognitif dan kognitif sosial menurut Schunk, contoh aplikasi prinsip-prinsip motivasi pembelajaran di kelas: (1) berika penjelasan bahwa siswa mampu mempelajari materi-materi yang diajarkan, (2) tunjukkan bagaimana pembelajaran tersebut berguna bagi kehidupan siswa, (3) mengajarkan siswa strategi pembelajaran dan menunjukkan mereka bagaimana strategi yang dipelajari berguna dalam meningkatkan kemampuan mereka, (4) tampilkan pembelajaran dengan cara yang dimengerti oleh siswa dan sesuaikan pembelajaran dengan perbedaan masing-masing cara belajar siswa, (5) upayakan siswa bekerja sesuai dengan tujuan pembelajaran, (6) pastikan bahwa feedback atribut yang diberikan sesuai dengan keadaan siswa (misalnya anda cukup pintar untuk mempelajari ini), (7) memberikan feedback pada saat terjadi peningkatan dalam pembelajaran dan kaitan reward dengan peningkatan yang terjadi pada pembelajaran siswa, (8) mengunakan modelmodel untuk self efficacy dan memperkuat motivasi [4]. 


\section{Pendekatan Konsepsi Sosiokultural}

Pandangan sosi kultural tentang motivasi menekankan partisipasi dalam kegiatan bermasyarakat. Orang terlibat dalam berbagai kegiatan untuk mempertahankan identitas dan relasi interpersonalnya dalam masyarakat. Jadi siswa akan termotivasi untuk belajar apabila mereka adalah anggota sebuah komunitas kelas atau sekolah yang memberi nilai tinggi pada belajar.

Menurut Schunk. seperangkat faktor-faktor pengaruh sosio kultural, yang berasal dari sebaya, keluarga, masyarakat, dan budaya [4]. Sementara itu Santrock hubungan dan konteks sosiokultural mengandung motivasi komponen sosial, selain motif untu berprestasi murid juga mempunyai motif sosial [4]. Bahasan tentang dimeni sosial ini terfokus pada motif sosial, hubungan sosial dan konteks sosio kultural murid.

Untuk mengaplikasikan prinsi-prinsip kepemipinan demokratis di kelas menurut Schunk dapat dilakuka melalui cara-cara sebagai berikut: (1) membina hubungan kolaboratif melalui kerjasama kelompok, (2) bertanya kepada anak dan meminta anak berbagi ide untuk menyelesaikan tugas-tugasnya, (3) mendorong pemecahan masalah dan pengambilan keputusan oleh anak, (4) memastikan bahwa anak memahami bahwa guru mempunya tanggungjawab dalam aktivitas kelas. [4]

Banyak contoh dalam pembelajaran di PAUD tidak tertanam dengan baik karena tidak konsistennya perlakuan di sekolah dengan di rumah. Misalnya disiplin yang biasanya di sekolah tidak diperkuat di rumah sehingga anak menghadapi dualisme kenyataan yang berbeda antara harapan di sekolah, keluarga dan di masyarakat. Konsistensi perlakuan sebaya, keluarga, dan masyarakat dan budayanya diperlukan untuk pengebangan sikap dan perilaku anak usia dini. Untuk itu orang tua juga perlu diperkuat dengan progran parenting atau dilibatkan dengan kegiatan anak di seklah.

\section{Aplikasi Motivasi dalam Pendidikan dan Pembelajaran bagi Anak Usia Dini}

Setiap anak yang mengikuti kegiatan belajar mengajar di kelas belum tentu mengalami belajar. Untuk itu Gartrell mengemukakan pengertian belajar dan pendidikan [7]. Belajar adalah apa yang dilakukan individu ketika ia menkonstruksi secara mental makna dari informasi. Belajar adalah pemerolehan pemahaman yang terjadi dalam domain-domain fisik, emosional, kognitif, sosial dan budaya. Proses tempat terjadinya pembelajaran adalah pendidikan baik pendidikan di rumah, di kelas dan di lingkungan. Penjelasan ini menunjukkan bahwa anak memperoleh pemahaman dalam domain fisik, emosional, kognitif, sosial dan budaya anak. Untuk itu dukungan terhadap anak dalam bentuk motivasi penting artinya dalam menstimulasi anak dalam belajar.

Stimulasi merupakan faktor penting terjadinya suatu pembelajaran karena ia akan menentukan sikap anak dalam belajar. Dalam kaitan itu maka Gagne dan Briggs mengemukakan pentingya sikap pada pembelajaran di sekolah [8]. Pertama, terbukti bahwa sikap guru dan sikap siswa untuk mengikuti pembelajaran, sikap terhadap kerjasama siswa dengan guru dan teman sekelas, sikap dalam memperhatikan pembelajaran dan sikap terhadap aktivitas pembelajaran itu sendiri semuanya penting dalam menentukan seberapa siap siswa tersebut dalam belajar. Kedua, Sikap kelas adalah segala sesuatu yang berkaitan dengan tujuan yang ingin dicapai sekolah atau perubahan sebagai hasil dari pembelajaran sekolah. Sikap toeransi dan dan kebersamaan merupakan merupakan tujuan dari pendidikan di sekolah. Sikap yang positif terhadap perolehan dan pembelajaran keterampilan baru dan ilmu penetahuan merupakan tujuan pendidikan yang penting bagi siswa. Kesukaan terhadap berbagai mata pelajaran dalam kurikulum sekolah seperti sain, kesusasteraan atau seni tergantung pada nilai yang diberikan pada mata pelajaran tersebut oleh sekolah. Terakhir, sikap mempunyai pengertian yang luas, biasanya disebut nilai-nilai, yang yang diharapkan sekolah untuk berkontribusi dan untuk dipengaruhi. Sikap yang diperlukan dalam perilaku sosial di sekolah misalnya kesamaan perlakuan, kejujuran, kedermawanan dan lain sebagainya.

Menurut Anderson dkk, secara umum motivasi belajar dalam model-model kognitif social dikemukakan bahwa terdapat tiga perangkat keyakinan yang memotivasi [1]. Pertama, keyakinan self efficacy yaitu anggapan siswa terhadap kemampuannya dalam menyelesaikan tugas tertentu. Kedua, keyakinan tehadap tujuan atau alasan yang dimiliki siswa mendorongnya untuk melakukan tugas tertentu (belajar untuk memperoleh nilai bagus). Ketiga, keyakinan terhadap nilai dan minat, menimbulkan persepsi siswa tentang minat diri (suka) pada suatu tugas 
termasuk penilainnya tentang bagaimana pentingnya dan bergunanya tugas tersebut bagi dirinya. Sebagai seorang siswa ia tidak hanya membutuhkan perkembangan pengetahuan tentang diri dan kesadaran tetang pengetahuan yang dimilikinya dan kognisi, ia juga butuh mengembangkan pengetahuan tentang diri dan kesadaran tentang motivasi yang dimilikinya. Kesadaran terhadap keyakinan memotivasi yang berbeda-beda ini dapat memampukan siswa memonitor dan menempatkan perilakunya dalam situasi pembelajaran sesuai dengan yang diharapkan.

Untuk mengkaji motivasi belajar termasuk motivasi belajar anak ada baiknya kita ikuti pernyataan Woofolk berikut ini. Menurut Woolfolk, para psikolog yang mempelajari motivasi memfokuskan pada lima pertanyaan dasar:

1. Apa pilihan yang dibuat anak tentang perilakunya?

2. Berapa lama waktu yang dibutuhkan anak untuk memulai?

3. Seberapa tinggi intensitas atau tingkat keterlibatan anak dalam kegiatan yang dipilih?

4. Apa yang menyebabkan anak tetap bertahan atau menyerah?

5. Apa yang dipikirkan dan dirasakan anak selama terlibat dalam kegiatan tersebut.

Penelitian dan teori mendukung pengalaman bermain sebagai sebuah dasar untuk program anak usia dini yang bermutu, tetapi semua anak tidak mendapatkan keuntungan secara penuh tanpa rencana, penataan lingkungan, dan pijakan orang dewasa untuk pengalaman. Pengalaman bermain anak seharusnya direncanakan dengan hati-hati dan diberi pijakan untuk memenuhi kebutuhan setiap anak. Empat langkah pijakan berikut ini untuk mencapai mutu pengalaman main: (1) Pijakan Lingkungan Main, (2) Pijakan Pengalaman Sebelum Main, (3) Pijakan Pengalaman Main Setiap anak, dan (4) Pijakan Pengalaman Setelah Main [9].

\section{METODE PENELITIAN}

Penelitian ini bersifat deskriptif analitik, yaitu data dideskripsikan dengan menggunakan statistik deskriptif, dan dimaknai secara mendalam berdasarkan perspektif emik yaitu penyajian data secara alamiah tanpa melakukan suatu manipulasi atau perlakuan terhadap subjek yang diteliti.
Disamping itu data deskriptif merupakan data hasil observasi observer yaitu mahasiswa PAUD yang ditugaskan untuk itu. Sebelum ke lapangan mahasiswa dibekali dengan informasi dan data yang akan diperoleh serta informasi lainnya yang terkait dengan gambaran guru dalam memtivasi anak.

\section{Tujuan Penelitian}

Berdasarkan pembatasan masalah dan perumusan masalah pada Bab I sebelumnya maka tujuan penelitian dapat dikemukakan sebagai berikut:

1. Untuk mengetahui gambaran pola motivasi guru PAUD dalam pembelajaran.

2. Untuk mengetahui perbedaan pola motivasi guru PAUD umum dengan guru PAUD Islam.

3. Untuk mengetahui hal yang melatar belakangi perbedaan pola guru PAUD dalam memotivasi murid dalam di PAUD.

\section{Tempat dan Waktu Penelitian}

Penelitian dilaksanakan di 47 Lembaga PAUD dengan rincian 30 Lembaga PAUD Islam dan 17 Lembaga PAUD Umum. Adapun lokasi Lembaga PAUD ini berada di sekitar Wilayah Jabodetabek. Sedangkan waktu penelitian berlangsung selama 9 (sembilan) bulan, yaitu dari bulan Maret 2012Nopember 2013.

\section{Ruang Lingkup dan Objek penelitian}

Ruang lingkup dan objek penelitian meliputi halhal sebagai berikut :

1. Wilayah penelitian ddilaksanakan pada 47 TK Islam dan TK Umum yang berada di Jabodetabek.

2. Sasaran Penelitian adalah guru-guru Lembaga PAUD Islam dan Lembaga PAUD guna mengetahui kecederungannya dalam memotivasi anak.

3. Penelitian hanya mengkaji kecenderungan Motivasi Guru Lembaga PAUD dan Guru Lembaga PAUD umum mahasiswa PAUD.

\section{Alat Pengumpul Data}

Alat pengumpulan data yang digunakan dalam penelitian ini adalah Lembar observasi yang diisi oleh mahasiswa yang ditugaskan untuk itu guna memperoleh gambaran memotivasi guru Lembaga PAUD yang diamatinya. Se;lanjutnya mahasiswa juga memberkan deskripsi terhadap kanyatan yang dihadapinya sesuai dengan pendekatan pada lembar observasi yang telah disediakan. 


\section{Pengolahan dan Analisis Data}

Berdasarkan data primer dan data sekunder yang diperoleh, maka pengolahan data selanjutnya diolah dan analisis dengan menggunakan analisis :

1. Analisis Statistik Deskriptif : data angket yang diisi oleh responden dianalisis dengan statistik deskriptif guna melihat kecenderungan data tentang pesrsepsi responden.

2. Analisis Kualitatif: data hasil analisis statistik deskriptif selanjutnya dijelaskan secara kualitatif melalui hasil deskripsi observasi dan wawancara dengan responden.

\section{HASIL PENELITIAN}

Pada bagian bab IV ini akan dibahas pendekatan motivasi yang dilakukan pada tahapan pembelajaran yaitu: penyambutan anak, pembukaan kegiatan belajar mengajar, kegiatan inti atau pada saat belajar mengajar, penutup kegiatan belajar mengajar, dan pelepasan anak pulang ke rumah.

\section{Penyambutan Anak}

Pendekatan motivasi behaviorisme dalam penyambutan anak merupakan bentuk motivasi yang umum digunakan oleh guru-guru baik di PAUD Islam maupun di PAUD umum. Adapun pendekatan berdasarkan perilaku ditandai dengan Memotivasi dengan cara memberikan penguatan positif atau negatif berupa benda atau kata-kata untuk memperkuat perilaku. Secara kasat mata terlihat bahwa guru merespon perilaku yang terlihat dari pengamatan guru. Artinya guru merespon perilaku murid berdasarkan yang terlihat.

Pada saat kedatangan terlihat bahwa guru menunggu anak di pintu gerbang dengan mengucapkan salam. Ada beberapa variasi penerimaan anak di pintu gerbang, menunggu di depan kelas sesuai dengan kondisi luasnya pekarangan sekolah. Sementara itu terdapat pula guru yang mengantar sampai ke kelas sambil memberikan penguatan positif kepada anak melalui gerakan tangan, ucapan yang bernada memuji untuk anak.

Dari lembaga PAUD Islam diketahui bahwa guru memberikan bintang pada anak yang datang lebih awal (16) dan barisan anak yang rapih dipersilahkan masuk kelas terlebih dahulu (19). Semua ini menunjukkan bahwa pendekatan motivasi yang lebih mendominasi adalah pendekatan behaviorisme.

Dari kedua sekolah baik sekolah umum secara umum terlihat tidak begitu terlihat pendekatan yang berbeda dari sudut pandang keagamaan. Hal ini terlihat bahwa di lembaga PAUD umum juga memberikan salam secara Islam. Artinya di beberapa sekolah atau lembaga umum juga didominasi oleh murid-murid yang berlatar belakang Islam. Perbedaan dalam pembelajaran agama pada hari tertentu seperti hari Jumat merupakan pembedaan kelas khusus untuk belajar agama sesuai dengan agama yang dianut oleh masing-masing anak.

Kesamaan pendekatan kedua ini dapat dilihat bahwa dalam prinsi-prinsip behaviorisme di kelas yaitu : (1) guru berupaya untuk memastikan bahwa anak siap untuk mengikuti kegiatan belajar, (2) guru membantu anak membentuk asosisasi antara kedatangan anak yang tepat waktu dengan kesiapan mereka untuk memasuki kelas, (3) memberi penguatan pada perilaku yang diharapkan dan memperlemah perilaku yang tidak diharapkan dengan menyapa anak, memberi bintang serta memberikan pujian atas penampilan anak.

Kesamaan lainnya antara lembaga PAUD Islam dengan Lembaga PAUD Umum dalam yaitu lembaga PAUD telah berupaya untuk mengaplikasikan prinsi-prinsip humanistik di kelas yaitu menunjukkan harapan yang positif pada siswa. Harapan guru yang positif terhadap siswa ini dapat dilihat dari ucapan guru: wah bagus sekali pakaian mu hari ini, menyapa dengan ramah, serta dan memuji anak yang datang ke sekolah tanpa didampingi orang tua (6).. Semua itu menunjukkan bahwa guru beruapaya untuk membuat anak merasa nyaman pada saat pertama sekali datang ke sekolah.

\section{Pembukaan Kegiatan Belajar Mengajar}

Sebelum kegiatan belajar mengajar yang telah direncanakan dilaksanakan di kelas dilaksanakan pembukaan kegiatan pembelajaran. Pembukaan kegiatan pembelajaran merupakan prakata/preview yang dapat memberikan gambaran awal terhadap apa yang akan dipelajari oleh anak dengan memberikan gambaran keterkaitannya dengan pembelajaran sebelumnya yang disebut scaffolding atau pijakan. Pijakan dimasudkan untuk memberikan pencerahan akan keterkaitan sesuatu yang akan dipelajari dengan hal yang telah dikuasai anak sebelumnya. Artinya pijkan 
merupakan jembatan untuk memasuki suatu pengetahuan, pengalaman, atau sikap baru atas pengetahuan, pengalaman, atau sikap yang telah dimilki sebelumnya.

Pembukaan pembelajaran pada kedua lembaga PAUD Islam dan lembaga PAUD umum lebih didominasi oleh aktivitas untuk berdoa. Kegiatan pembukaan pembelajaran belum menyentuh esensi kegiatan yang akan dilaksanakan sesuai dengan tujuan pembelajaran. Ini berarti antara pembukaan dan pembelajaran yang akan dilaksanakan belum memberikan gambaran tentang apa yang akan dilakukan dalam kegiatan pembelajaran, utamanya kegiatan pembelajaran yang masih bersifat klasikal.

Dalam pembelajaran yang bersifat klasikal lebih menguatamakan perilaku yang tampak yaitu mengacu pada prinsip pembelajaran behaviorisme. Dalam aktivitas pembelajaran behavirisme terlihat bahwa: (1) guru berupaya untuk memastikan bahwa anak siap untuk belajar, (2) guru membantu anak membentuk asosisasi antara stimulus dan respon, (3) guru memberikan gambaran tentang belajar dan aktivitas kelas dengan hasil yang menyenangkan, (4) memberi penguatan pada perilaku yang diharapkan dan memperlemah perilaku yang tidak diharapkan, (5) memberi penguatan kemajuan dalam pembelajaran dan perilaku, (6) memberikan kesempatan berpartisipasi pada aktivitas yang bernilai dan mengurangi kegiatan-kegiatan yang kurang bermanfaat.

Lain halnya dengan lembaga yang telah mengebangkan pembelajaran berbasis sentra baik di lembaga PAUD Islam maupun lembaga PAUD umum. Lembaga ini telah mulai menggunakan landasan berpijak sebelum kegoatan pembelajaran. Landasan dalam pembukaan pembelajaran merupakan bagian penting untuk menjembatani kegiatan selanjutnya yang umumnya disebut sebagai pijakan. Menurut CCCRT, pijakan pengalaman sebelum main antara lain mengembangkan: (1) membaca buku yang berkaitan dengan pengalaman atau mendatangkan nara sumber, (2) menggabungkan kosakata baru dan menunjukkan konsep yang mendukung perolehan keterampilan kerja (Standar Kinerja), (3) memberikan gagasan bagaimana menggunakan bahan-bahan, (4) mendiskusikan aturan dan harapan untuk pengalaman main, (5) menjelaskan rangkaian waktu main, (6) mengelola anak untuk keberhasilan hubungan sosial, dan (6) merancang dan menerapkan urutan transisi main

\section{Kegiatan Inti pada Saat Kegiatan Belajar Mengajar}

Kegiatan inti merupakan kegiatan utama dalam pembelajaran. Dalam kegiatan inti mengacu kepada tujuan pembelajaran yang telah direncanakan sebelumnya. Artinya kegiatan inti mengarah kepada aktivitas-aktivitas yang memberikan kemungkinan untuk pencapaian tujuan pembelajaran.

Dalam kaitan itu maka aktivitas pembelajaran anak harus dapat mengaktifkan seluruh inderanya sehingga berbagai macam bentuk variasi gaya belajar anak dapat terakomodasi. Disamping itu pengembangan materi yang sesuai dengan media pembelajaran merupakan hal lain yang secara sistemik mengacu kepada disain pembelajaran yang dikembangkan oleh guru.

Prinsip-prinsip motivasi behaviorisme di kelas masih mendominasi kegiatan dalam kegiatan inti. Hal ini terlihat antara lain: guru berusaha untuk bantu anak membentuk asosisasi antara stimulus dan respon yaitu seperti memberikan pujian kepada anak yang dapat menjawab dengan benar, pintarnya ngerjainnya, bagus gambarnya. Namun secara spesifik guru belum menjelaskan pencapaian anak sesuai dengan kriteria yang ditentukan. Pendekatan motivasi behaviorisme ini tergambar jelas pada saat guru: (1) memberikan gambaran tentang belajar dan aktivitas kelas dengan hasil yang menyenangkan, (2) memberi penguatan pada perilaku yang diharapkan dan memperlemah perilaku yang tidak diharapkan, (3) memberi penguatan kemajuan dalam pembelajaran dan perilaku, (4) memberikan kesempatan berpartisipasi pada aktivitas yang bernilai dan mengurangi kegiatan-kegiatan yang kurang bermanfaat.

Pendekatan bevaviorisme lebih kentara dalam kegiatan kelas yang bersifat klasikal. Namun dalam kegiatan pembelajaran yang berbasis sentra: (1) telah memberikan kemungkinan kepada anak untuk pertumbuhan personal dengan memberikan kesempatan pada siswa untuk memilih dan kesempatan untuk memulai aktivitas pembelajaran dan pencapaian tujuan, (2) membuat kontrak dan memberi kesempatan kepada siswa untuk mengevaluasi pembelajaran mereka, (3) memfasilitasi pembelajaran dengan menyediakan sumber-sumber belajar dan penguatan bagi siswa. 


\section{Penutup Kegiatan Pembelajaran}

Pendekatan motivasi dalam penutup baik PAUD Islam maupun PAUD umum masih didominasi oleh pemberian pengauata positif atau penguatan negatif untuk membentuk perilaku anak. Hal ini terlihat dari pemberian bintang dan penarikan bintang untuk bagi anak yang melanggar normanorma yang berlaku. Sebagian guru telah melakukan mengingat ulang pengalaman yang dialami anak saat melakukan aktivitas inti dan menggunakan waktu untuk beres-beres alat main.

Kegiatan beres-beres merupakan bagian penting pada kegiatan sentra, saat yang tepat untuk membangun semua domain perkembangan anak (estetika, afeksi, kognisi, bahasa, psikomotor, dan social), diakhir kegiatan main anak. Setelah kegiatan beres-beres selesai, guru mengajak anak untuk berkumpul duduk membuat lingkaran, mengingat kembali kegiatan-kegiatan apa saja yang telah dilakukan. Masing-masing anak saling menceritakan pengalaman mainnya.

Dalam kegiatan penutup lembaga PAUD Islam dan lembaga PAUD Umum relatif sama. Kesamaan tersebut dapat dilihat pada tabel di atas bahwa anak diminta untuk menceritakan apa yang telah terjadi dalam kegiatan pembelajaran. Guru juga mendiskusikan apa yang telah terjadi pada saat pembelajaran. Kegiatan ini tidak haya terjadi pada kelas yang berbasis sentra tetapi juga dikembangkan dalam kelas yang masih bersifat klasikal. Kegiatan ini sudah mulai sejalan dengan apa yang dikemukakan oleh CCCRT bahwa Pijakan Pengalaman Setelah Main adalah dengan: (1) mendukung anak untuk mengingat kembali pengalaman mainnya dan saling menceritakan pengalaman mainnya, dan (2) menggunakan waktu membereskan sebagai pengalaman belajar positif melalui pengelompokan, urutan, dan penataan lingkungan main secara tepat [9].

\section{Pelepasan Anak Pulang ke Rumah}

Telah banyak diketahui bahwa aktivitas di rumah seringkali tidak sejalan dengan aktivitas penanaman nilai di rumah. Untuk pengingatan kembali apa yang dipelajari di sekolah perlu disampaikan kepada anak agar sikap dan perilakunya diperkuat secara konsisten di rumah. Pengalaman menunjukkan tidak terdapat konsistensi penanaman sikap dan perilaku di sekolah dengan aktivitas anak di rumah. Untuk itu guru perlu tetap mengontrol anak saat keberadaannya di rumah.
Faktor motivasi guru tidak hanya diperlukan di sekolah tetapi diprlukan untuk memperkuat penanaman nilai di rumah. Seringkali anak mengucapkan kata-kata yang mengacu kepada apa yang disampaikan oleh guru, "kata ibu tidak begitu, kata ibu begini." Kenyataan ini menunjukkan bahwa aperan guru telah memasuki kehidupan anak anak sehingga apapun yang disampaikan orang tua dikonfirmasi kepada apa yang disampaikan oleh guru. Ini berarti [pula bahwa apabila penyampaian guru salah maka apa yang diyakini anak juga akan salah dan akan mempengaruhi kehidupannya sepanjang hari dan mungkin sepanjang hayatnya.

Kegiatan utama dalam pelepasan anak pulang ke rumah lebih pada kegitan berdoa, bernyanyi dan mengantar atau menunggui anak sampai jemputan atau orang tua datang. Dari data observasi yang dikemukakan di atas terlihat bahwa PAUD Islam lebih berorientasi pada pendekatan perilaku, sedangkan PAUD umum relatif lebih beragam walaupun pendekatan utama yang digunakan tetap pendekatan perilaku (behaviorisme). Ini berarti bahwa memotivasi dengan memberikan penguatan positif atau negatif berupa benda atau kata-kata untuk memperkuat perilaku.

Dalam kegiatan pelepasan anak pulang belum menunjukkan upaya untuk sinkronisasi atau keselarasan apa yang dipelajari di sekolah dengan pemahaman orang tua di ri rumah. Pada saat anak di lepas pulang guru hampir tidak pernah menjelaskan apa yang dipelajari anak di sekolah atau apa perkembangan yang terjadi di sekolah pada hari tersebut.

\section{Pembahasan}

Tujuan pembelajaran adalah untuk mendidik anak menjadi pebelajar mandiri. Pembelajar mandiri mengandung pengertian bahwa anak merupakan subjek belajar yang tumbuh dan berkembang atas keinginan dan kemauan anak untuk belajar sepajang hayatnya. Untuk itu bekal yang harus diberikan kepada anak dalam belajar adalah bagaimana cara belajar sesuai dengan gaya belajarnya tetapi juga perlu dibekali dengan pola belajar lainnya yang dapat menggali potensi anak secara optimal. Selain itu pembelajaran yang baik adalah pembelajaran yang mendorong berkembangnya potensi anak secara optimal.

Pembelajaran dengan demikian adalah upaya untuk mengoptimalkan potensi yang dimiliki oleh anak. Untuk itu pembelajaran yang baik 
memberikan kesempatan kepada anak seluasluasnya untuk mengembangkan potensi yang dimilikinya. Oleh sebab itu pula Dirjen Pendidikan Dasar yang membawahi TK pada saat itu telah menerbitkan surat Edaran tentang pelarangan mengajar menulis dan membaca bagi anak Taman Kanak-Kanak. Walaupun kita semua tahu bahwa surat edaran tersebut tidak terlalu efektif untuk memberikan kesadaran kepada masyarakat dan orang tua yang selalu berharap agar anaknya dapat membaca menulis dan berhitung pada saat memasuki Sekolah Dasar (SD). Rendahnya kesadaran ini diperkuat dengan maraknya sekolah yang mewajibkan anak lulus tes membaca menulis dan berhitung untuk masuk SD. Biasanya sekolah yang mewajibkan lulus membaca, menulis dan berhitung ini terhitung sekolah favorit sehingga banyak orang tua yang cemas kalau anak mereka tidak dapat masuk sekolah favorit tersebut.

Permasalahan ini makin menjadi faktor penghambat pengembangan potensi anak untuk mengembangkan potensinya selain kecerdasan bahasa seperti membaca dan menulis serta kecerdasan kognitif seperti berhitung atau Matematika. Sehingga waktu guru dihabiskan untuk mendorong anak agar segera cepat pandai membaca, menulis dan berhitung sesuai dengan permintaan pasar.

Sesungguhnya banyak potensi anak yang harus dikembangkan seperti sosial, emosional, naturalistik dan seni yang banyak diperlukan dalam kehidupan manusia. Untuk itu pendekatan guru dalam mengajar mempunyai peran penting dalam mengubah pola pikir sempit dalam pembelajaran Anak Usia Dini dengan cara pendekatan pembelajaran yang lebih kondusif bagi anak untuk belajar agar lebih mandiri atau berorientasi pada anak, sekaligus juga memberikan kesempatan kepada anak untuk secara sistematis membentuk pola belajar anak secara mandiri kelak dikemudian hari. .

Pendekatan pembelajaran yang lebih berorientasi anak memberikan berbagai kemungkinan pengembangan potensi anak melalui sumber belajar yang lebih luas dan kaya dari sekedar instruksi dari guru. Peluang yang besar dari interaksi anak dalam keseharian harus dapat memberikan kesempatan kepada anak untuk memperoleh pengalaman yang kaya dalam merespon lingkungannya. Untuk itu pendekatan motivasi yang digunakan oleh guru dalam mengajar akan menimbulkan konsekuensi yang sangat besar dalam mengembangkan cara anak dalam belajar.

Untuk itu bagaimana guru dapat menciptakan lingkungan belajar. Dalam kaitan itu Bentzen mengatakan bahwa berada dalam lingkungan umum dan merupakan suatu lingkungan dalam suatu tindakan [10]. Keberadaan lingkungan umum tidak tergantung pada siapapun atau apapun lainnya (misalnya pengecualian menempatkan barang-barang rusak, menambah peralatan baru, atau mengatur ulang peralatan dan materi-materi). Sedangkan lingkungan perkembangan, bahkan bersifat dinamis, dan selalu mengalami perubahan. Misalnya, sebagai bagian dari lingkungan umum, kayu dalam bentuk balok secara esensial berarti konstan, tetapi sebagai bagian lingkungan perkembangan, kayu balok dapat berarti banyak makna dan berguna sebagai alat main bagi anak. Dalam perasaan yang bersifat objektif, kayu balok adalah kayu balok; dalam perasaan subjektif berarti apa kegunaan kayu balok itu bagi anak. Lingkungan perkembangan sangat bersifat subjektif.

Berkaitan dengan lingkungan yang bersifat subjektif tersebut peran guru dalam memotivasi merupakan faktor penting dalam pembelajaran anak. Dalam pengasuhan, interaksi mempunyai makna yang lebih mendalam dari sekedar pertukaran secara pribadi, yang antara lain disebabkan oleh gaya belajar. Merupakan konsekuensi dari perubahan perkembangan, pembelajaran, emosi yang dialami anak selama berada dalam setting pengasuhan pada waktu tertentu dalam perkembangan mereka. Pengasuhan yang efektif berupaya untuk memaksimalkan efek interaksi dengan cara mengembangkan pengalaman bagi anak yang lebih cocok dengan kebutuhan perkembangan, kepribadian, bakat, minat serta temperamen anak. Walaupun respon individual terhadap lingkungan fisik kelihatannya sama, persepsi, pengertian, dan perasaan dapat berbeda secara berarti. Pengertian masing-masing anak dalam merespon terhadap lingkungan bersifat unik dan keunikan tersebut berguna untuk mengembangkan kurikulum sesuai anak.Efektivitas suatu program dalam suatu fungsi tentang berbagai macam efek interaksi benar-benar terpenuhi.

Dalam kaitan pembelajaran yang dilakukan seorang guru membentuk nilai-nilai belajar bagi anak. Dalam kaitan itu Spodek mengemukakan bahwa sikap dan nilai-nilai merupakan aspek yang 
berarti dalam pendidikan anak usia dini [11]. Dalam beberapa hal nilai-nilai dipelajari dalam bentuk konsep yang dipelajari. Seorang anak mempunyai harapan, kejadian yang dialami dan mencari jawaban-jawaban dari hal yang diharapkannnya. Orang yang termasuk berarti bagi anak biasanya memandu anak dalam menguji cobakan harapan-harapan yang dimilikinya, melayani sebagai model yang ditiru oleh anak. Sepanjang anak menganggap gurunya sebagai model maka, guru perlu memberikan contoh positif bagi anak untuk diikutinya. Dalam pembelajaran di sekolah dan nilai-nilai di masyarakat anak-anak meniru model yang tersedia. Guru harus mendorong anak untuk meniru pola-pola perilaku yang diinginkan sesuai dengan yang mereka miliki. Anak-anak perlu belajar membedakan nilai-nilai sosial yang cocok guna menjadi pertimbangan dalam menghargai perasaan orang lain.

Selanjutnya kebutuhan Perkembangan mempunyai premis utama adalah perkembangan itu sendiri adalah suatu kebutuhan. Perkembangan berkaitan dengan dua hal: (1) kemampuan anak pada waktu tertentu dalam sejarah perkembangannya, dan bagaimana kemampuan-kemampuan ini berubah, dan (2) kebutuhan anak pada waktu tertentu dalam sejarah perkembangannya, dan bagaimana kebutuhan-kebutuhan ini berubah.

Untuk itu rutinitas merupakan aktivitas keseharian anak yang perlu dicermati guna mengembangkan anak sesuai dengan kebutuhan perkembangannya. Menurut Morrison dalam kurikulum perlu dibangun rutinitas dan tujuan tujuan program sehari-hari [12].

Rutinitas meliputi: (a) kedatangan dan kepulangan; (b) diapering and toiletting; (c) feeding, waktu makan, dan kudapan; dan (d) tidur siang dan waktu tidur. Pengorganisasian kurikulum berkaitan dengan rutinitas dan rutinitas itu sendiri memberikan pemahaman kepada anak tentang konsistensi, rasa aman, keamanan, meningkatkan rasa percaya dan rasa nyaman secara umum. Sehubungan dengan hal tersebut maka pembahasan pendekatan motivasi dalam pembelajaran akan dibahas tentang pendekatan motivasi dalam: (1) penyambutan anak, (2) pembukaan kegiatan belajar, (3) kegiatan inti atau pada saat pembelajaran berlangsung, (4) penutup kegiatan pembelajaran, dan (5) pelepasan anak pulang ke rumah. Untuk lebih jelasnya akan diuraikan satu persatu sebagai berikut:
Dalam aktivitas pembelajaran di lembaga PAUD Islam dan lembaga PAUD umum belum menunjukkan rutinitas sebagai suat kesatuan yang tidak terpisahkan. Kegiatan tahapan rutinitas masih terpisah satu sama lainnya dalam mengemban suatu misi untuk membentuk nilai-nilai esensi pembelajaran kedalam suatu aktivitas pembentukan nilai-nilai yang dipelajari. Kegiatan penyambutan, kegaiatan pembukaan belu merupakan satu kesatuan yang selaras dengan tujuan pembelajaran pada kegiatan inti. Namun telah terlihat keselarasan antara kegiatan inti dengan kegiatan penutup yaitu melalui kegiatan review kegiatan yang telah dilakukan pada kegiatan inti.

Selain itu pernyataan morivasi yang dikemukakan dalam proses pembelajaran masih bersifat penghargaan terhadap produk yang dihasilkan oleh anak. Sementara itu penghargaan terhadap proses belum mendapat perhatian yang memadai. Untuk dapat mendorong guru agar lebih menekankan pada penghargaan terhadap proses pencapaian hasil dalam pembelajaran dapat mengacu kepada aktivitas yang berproses dalam aktivitas pembelajaran.

Dalam aktivitas berorientasi proses harus dapat menggambarkan aktivitas yang mengacu kepada kesiapan anak dalam kegiatan pembelajaran. Dalam kaitan aktivitas tersebut Wolfgang (1981:06) mengemukakan bahwa dengan mudah gambaran bagaimana perkembangan bermain anak dapat mempengaruhi bentuk-bentuk kegiatan dalam bermain yang dapat dikembangkan dalam bermain sebagaimana terlihat pada Gambar 1 .

\section{Perkembangan Bermain Sosial}

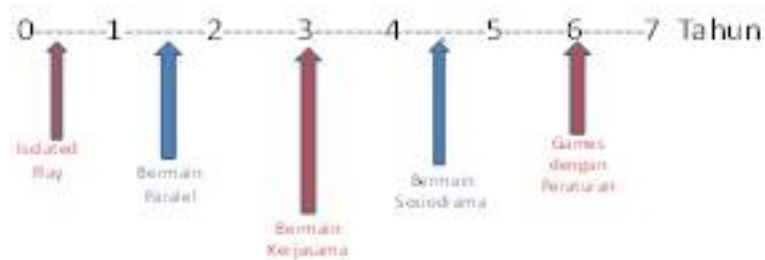

Gambar 1. Perkembangan bermain sosial

Sehubungan dengan perkembangan bermain sosial yang dikemukakan di atas dapat dipahami bahwa tata cara intervensi guru terhadap aktivitas belajar anak mesti disesuaikan dengan perkembangan pembelajaran anak secara individual. Walaupun 
diketahui bahwa pembelajaran indiviudal sulit dilakukan dalam bentuk pembelajaran yang umumnya bersifat klasikal karena keterbatasan jumlah guru yang mengajar. Untuk itu Wolfgang mengemukakan ada 5 skala pendampingan Guru / orang dewasa diwaktu anak main ; pengamatan secara Visual (Visually looking on), (2) pernyataan tanpa mengarahkan (Non directive statement), (3) pernyataan (Question), (4) Pernyataan Mengarahkan (Directive statement), (5) Pernyataan melalui Contoh secara Fisik (Physical Stament) [13].

Skala pendapingan anak dalam pembelajaran akan menimbulkan efek pembelajaran yang sangat besar kepada anak. Untuk itu pula Bentzen mengatakan bahwa efek interaksi merupakan konsekuensi dari perubahan perkembangan, pembelajaran, emosi yang dialami anak selama berada dalam setting pengasuhan pada waktu tertentu dalam perkembangan mereka [10]. Pengasuhan yang efektif berupaya untuk memaksimalkan efek interaksi dengan cara mengembangkan pengalaman bagi anak yang lebih cocok dengan kebutuhan perkembangan, kepribadian, bakat, minat serta temperamen anak.

Berdasarkan kenyataan di atas maka perlu diketahui bahwa walaupun respon individual terhadap lingkungan fisik kelihatannya sama, persepsi, pengertian, dan perasaan dapat berbeda secara berarti. Pengertian masing-masing anak dalam merespon terhadap lingkungan bersifat unik dan keunikan tersebut berguna untuk mengembangkan kurikulum sesuai anak. Efektivitas suatu program dalam suatu fungsi tentang berbagai macam efek interaksi benarbenar terpenuhi.

Motivasi dalam kegiatan inti belum dimanfaatkan untuk berbagai untuk memperluas pengalaman anak anak dalam aktivitas pembelajaran. Untuk itu dalam memotivasi dengan mempelajari model tindakan yang cocok dengan cara anak mengamati konsekuensi tindakan tersebut. Menurut CCRT bahwa pijakan Pengalaman Main Setiap Anak dapat memberikan isnpoirasi anak dalam belajar sebagai yang dikemukakan berikut ini: (1)memberikan anak waktu untuk mengelola dan memperluas pengalaman main mereka, (2)mencontohkan komunikasi yang tepat, (3) memperkuat dan memperluas bahasa anak, (4) meningkatkan kesempatan sosialisasi melalui dukungan pada hubungan teman sebaya, dan (5) mengamati dan mendokumentasikan perkembangan dan kemajuan main anak [9].

Sementara itu memotivasi dengan menekankan sumber-sumber instrinsik dengan rasa kompetensi, self-esteem, otonomi dan aktualisasi diri mereka (misalnya kamu pasti bisadll) sudah terlihat dalam mendorong anak untuk belajar lebih keras atau berusaha lebih keras untuk menyelesaikan tugastugas.

Sedangkan pendekatan kognitif sosial yaiu memotivasi dengan mempelajari model tindakan yang cocok dengan cara anak mengamati konsekuensi tindakan tersebut masih sangat rendah. Hal ini dapat dipahami karena keterbatasan jumlah guru dan aktivitas yang pada umumnya bersifat klasikal. Pendekatan yang menggunakan penguatan atas dasar pengamatan memerlukan intensitas kegiatan yang sifanya indvidual, sedangkan pendekatan baru dilakukan lebih pada pendekatan klasikal. Beruntung bagi lembaga PAUD yang telah mengembangkan aktivitas berbasis sentra walaupun mungkin tidak dari motivasi yang dikembangkan oleh guru, paling tidak anak belajar dengan sendirinya atas apa yang dilakukan secara individual di sentra masing.

Dalam kaitan itu Jean Piaget mengemukakan tentang bagaimana anak belajar: "Anak seharusnya mampu melakukan percobaan dan penelitian sendiri. Guru, tentu saja, bisa menuntun anak-anak dengan menyediakan bahan-bahan yang tepat, tetapi yang terpenting agar anak dapat memahami sesuatu, ia harus membangun pengertian itu sendiri, ia harus menemukannya sendiri."

Hal ini menunjukkan bahwa pendekatan motivasi yang bervariasi dapat mendorong berbagai kemungkinan pengembangan pembelajaran yang dapat mengakomodasi perkembangan secara individual maaupun perkembangan secara kelompok. Apabila sekolah merupakan representasi masyarakat sekolah maka seyogialanya kegiatan sekolah harus mendorong pendekatan motivasi yang bersifat perilaku, kemanusiaan, kognitif sosial maupun sosio kultural.

Pendekatan motivasi yang bervariasi tersebut tidak hanya mendorong perkembangan perilaku yang tampak dari anak tetapi perlu anak dapat mengembangkan kepribadian, kebebasan untuk memilih berbagai kegiatan positif yang 
diminatinya. Dalam pemilihan tersebut harus mempertimbangkan pengetahuan, aturan-aturan, keterampilan, strategi, keyakinan dan emosi dengan mengamati model yang ada dilingkungannya baik dari teman sebaya, maupun dari guru dan administrator lembaga di sekolah tersebut. Dengan melakukan pengamatan terhadap model yang ada di sekolah anak dapat mempelajari semua bentuk konsekuensi tindakan yang dilakukannya. Dengan kata lain sekolah sebagai sebuah komunitas merupakan Sosio kultural yang berasal dari sebaya, keluarga, masyarakat, dan budaya. Hal ini berarti pula bahwa motivasi komponen sosial, selain motif untuk berprestasi murid juga mempunyai motif sosial.

\section{KESIMPULAN DAN SARAN}

\section{Kesimpulan}

Berdasarkan hasil penelitian yang dikemukakan pada bab IV sebelumnya maka dapat disimulkan hal sebagai berikut:

1. Gambaran pola motivasi guru PAUD dalam pembelajaran antara guru lembaga PAUD Islam dan guru lembaga PAUD Umum lebih menekankan kepada pola motivasi behavioristik walaupun demikian pola pendekatan PAUD umum lebih bervariasi dalam menggunakan pola humanistik. Namun baik lembaga PAUD Islam dan lembaga PAUD Umum belum menerapkan kognitif sosial dan sosiolultural.

2. Perbedaan pola motivasi guru PAUD umum dengan guru PAUD Islam dapat dibedakan bahwa PAUD dalam pendekatan pembelajaran klasikal dan berbasis sentra. Kelas yang berbasis klasikal lebih beroientasi guru sementara kelas yang berbasis sentra dapat memberikan kesempatan yang lebih luas pada anak. Hal ini mempunyai implikasi bahwa kelas berbasis sentra lebih berani dalam bereksperimen untuk menggunakan pendekatan-pendekatan baru dalam memotivasi juka dibandingkan dengan pembelajaran yang bersifak klasikal.

3. Latar belakang perbedaan pola guru PAUD dalam memotivasi murid dalam di PAUD antara lain disebabkan oleh rasa ingin melakukan perbaikan pembelajaran membaca menulis dan berhitung sehingga pendekatan motivasi bersifat behaviriostik lebih terukur dan dapat diamati. Disamping itu pendekatan motivasi juga dipengaruhi oleh orientasi pembelajaran berbasis klasikal atau berbasis sentra yang dapat mempengaruhi dominasi guru atau dominasi murid dalam proses pembelajaran.

\section{Saran}

Berdasarkan hasil penelitian dan kesimpulan yang dikemukakan sebelumnya maka disarankan halsebagai berikut:

1. Perlu sosialisasi dan evaluasi penekanan pembelajaran yang beorientasi pada membaca, menulis dan berhitung sebagai bagian dalam pembinaan PAUD pendekatan pembelajaran berbasis sentra sehingga dominasi guru dapat berubah menjadi dominasi anak dalam pembelajaran. .

2. Agar guru-guru PAUD didorong untuk melakukan eksperimen pembelajaran dengan memberdatakan teman sejawat sehingga keinginan untuk mengubah pola motivasi pembelajaran berkembang secara massif di kalangan guru PAUD.

3. Guru didorong untuk mengubah mengebangkan pembelajaran yang berorientasi membaca, menulis dan berhitung dengan mengoptimalkan seluruh potensi kecerdasan anak.

\section{DAFTAR PUSTAKA}

[1] Anderson, Lorin W., David R. Krathwoh et.al, (2001) A Taxonomiy for Learning Teaching and Assessing: A Revision of Bloom's Taxonomy of Educational Objectives, Abridged Edition, (New York: Longman)

[2] Zais, Robert S. (1976) Curriculum :Principle and Foundation (New York: Harper \& Row, Publisher)

[3] Geswicki, Caroll. (2007) Developmentally Appropriate Practice: Curriculum and Development in Early Education. Third Edition (New York:Thomson Delmar Learning)

[4] Schunk dkk. (2008) Motivation in Education: Theory, Research and Application (New Jersey: Pearson Merril Prentice Hall)

[5] Woolfolk, Anita. (2009) Educational Psychology: Active Learning, Terjemahan oleh Drs. Helly Prajitno Soetjpto dan Dra. Sri Mulyatini Soetjipto, (Yokyakarta: Pustaka Pelajar)

[6] Santrock, Jhon W. (2004) Educational Psychology , $2^{\text {nd }}$ Edition dialih bahasakan oleh Tri Wibowo Bs. (Jakarta:Kencana Predana Media Group)

[7] Gartrell, Dan. (2003) A Guidance Approach for Encouraging Classroom, Third Edition (New York:Thomson Delmar Learning)

[8] Gagne, Robert M.dan Leslie J. Briggs. (1978) Principles of Instructional Design, Second Edition (New York:Holt Rinehart and Winston) 
[9] CCCRT (2004) Lebih Jauh Tentang Sentra dan Saat Lingkaran: Pandangan Bermain (Jakarta:CCCRT)

[10] Bentzen, Warren R., dan Martha B. Frost. (2003) Seeing Child Care: A Guide for Assessing the Effectiveness of Child Care Program (New York: Thomson Delmar Learning)

[11] Spodek, Bernard, Olivia N. Saracho dan Michael D. Davis. (1991) Foundation of Early Childhood Education: Teaching Three, Four and Five-ears-
Old Children, Second Edition, (Boston: Allyn and Bacon)

[12] Morrison, George S. (2008) Fundamentals of Early Childhood Education Fifth Edition (New Jersey: Pearson Merrill Prentice Hall)

[13] Wolfgang, Charles H., Bea Mackender dan Mary E. Wolfgang (1981) Activities for Preschool and Kindergarten: Growing \& Learning Through Play, a Parent/caregiver Book (USA: Judy/Instruction) 